\title{
Acute bacterial infections of the eye: their aetiology and treatment
}

\author{
V. M. MAHAJAN \\ From the Ocular Microbiology Section of Dr Rajendra Prasad Centre for Ophthalmic Sciences, \\ All-India Institute of Medical Sciences, New Delhi-110029, India
}

SUMMARY The aerobic microbial flora of 823 eyes with acute bacterial conjunctivitis, corneal ulceration, dacryocystitis, discharging sockets, blepharitis, and postoperative infections has been investigated. Staphylococci, Streptococcus pneumoniae, and nonfermenting Gram-negative bacilli including Pseudomonas aeruginosa were the main pathogens. Fermenting coliforms were also infrequently isolated. The least overall resistance of $30.9 \%$ was to chloramphenicol, but no one antibiotic was effective against all pathogens. Cloxacillin is the best drug for staphylococcal and polymyxin B for pseudomonas infections.

The bacterial pathogens causing acute bacterial infections of the eye and their pattern of antibiotic sensitivity have recently been reported from the United Kingdom and the United States of America. ${ }^{1-3}$ These types of pathogenic bacteria have gradually changed over the years, as have their antibiotic sensitivities. We carried out the present study to identify current pathogens in various acute conditions and to determine the most appropriate antibiotics for their treatment.

\section{Materials and methods}

The patients (543 eyes) were examined clinically in the Outpatient Department and admitted to hospital in the Dr Rajendra Prasad Centre for Ophthalmic Sciences during January to June 1981 before bacteriological specimens were taken from their eyes. Culturing of conjunctivae, lid margins, or sockets was done with sterile cotton-wool swabs. No transport medium was used, since the swabs were streaked on to sheep blood agar medium without any appreciable delay. Only aerobic cultures were done. Bacteria were identified by standard laboratory procedures. The sensitivity of these organisms to penicillin (10 units), streptomycin $(15 \mu \mathrm{g})$, tetracycline $(30 \mu \mathrm{g})$, chloramphenicol $(10 \mu \mathrm{g})$, erythromycin $(15 \mu \mathrm{g})$, framycetin $(30 \mu \mathrm{g})$, gentamicin $(10 \mu \mathrm{g})$, cloxacillin (1 $\mu \mathrm{g})$, and polymyxin B (300 units) was tested by the disc diffusion technique, and the results were

Correspondence to Dr V. M. Mahajan. interpreted as recommended by Bauer et $a l .{ }^{4}$ Resistant strains of pseudomonas were tested against $10 \mu \mathrm{g}$ of tobramycin.

Control cultures (280 eyes) were taken from patients who had come mostly for cataract extraction. Only clinically were clean eyes chosen. Postoperative infections included surgical wounds, endophthalmitis, and infections of the buckle or the corneal grafts.

\section{Results}

The percentage isolation rates of bacteria for each clinical category are given in Table 1 . The percentage rates of antibiotic resistance for the various bacteria isolated are listed in Table 2 except those from postoperative infections, which have been separately shown in Table 3, for such infections in hospital patients could well be due to hospital strains.

\section{Discussion}

Staphylococcus epidermidis was isolated in pure cultures from $37 \cdot 1 \%$ of normal conjunctival controls. No lid cultures were made from control subjects, since no significant difference has been reported to occur in the floras recovered from the eyelid margins and the conjunctiva. ${ }^{5}$ Staph. aureus was found in $6.4 \%$ of the normal sacs as a pure growth. The lower rates in our study ${ }^{135}$ are in all probability due to the use of dry cotton swabs for collection of material and not using a suitable transport medium to preserve the 191 
Table 1 Aerobes isolated from ocular tissues

\begin{tabular}{|c|c|c|c|c|c|c|c|c|c|}
\hline \multirow[t]{2}{*}{ Clinical condition } & \multicolumn{8}{|c|}{ Percentage isolation rates } & \multirow{2}{*}{$\begin{array}{l}\text { Total no. of } \\
\text { eves/sockets }\end{array}$} \\
\hline & $\begin{array}{l}\text { Staph. } \\
\text { aureus }\end{array}$ & $\begin{array}{l}\text { Staph. } \\
\text { epidermidis }\end{array}$ & $\begin{array}{l}\text { Str. } \\
\text { pneumoniae }\end{array}$ & $\begin{array}{l}\text { Ps. } \\
\text { aeruginosa }\end{array}$ & $\begin{array}{l}\text { Acineto- } \\
\text { bacter }\end{array}$ & Coliforms & $\begin{array}{l}\text { Mixed } \\
\text { growth }\end{array}$ & $\begin{array}{l}\text { No } \\
\text { growth }\end{array}$ & \\
\hline Normal controls & $6 \cdot 4$ & $37 \cdot 1$ & $0) \cdot 3$ & 0.7 & $1 \cdot()$ & - & $2 \cdot 4$ & $51 \cdot 8$ & 280 \\
\hline Conjunctivitis & $18 \cdot 7$ & $16 \cdot 2$ & $7 \cdot 5$ & $1 \cdot 2$ & $1 \cdot 2$ & $1 \cdot 2$ & $1 \cdot 2^{*}$ & $52 \cdot 5$ & 80 \\
\hline Corneal ulceration & $23 \cdot 2$ & $26 \cdot()$ & $2 \cdot 7$ & $6 \cdot 8$ & - & $1 \cdot 3$ & $1 \cdot 3 \dagger$ & $39 \cdot()$ & 73 \\
\hline Dacryocystitis & $14 \cdot 6$ & $12 \cdot()$ & $33 \cdot 3$ & $4 \cdot()$ & $1 \cdot 3$ & $2 \cdot 6$ & - & $32 \cdot 0$ & 75 \\
\hline Discharging sockets & $22 \cdot 5$ & $16 \cdot 1$ & $9 \cdot 6$ & $9 \cdot 6$ & $3 \cdot 2$ & - & $3 \cdot 2 \div$ & $35 \cdot 4$ & 31 \\
\hline Fellow eyes & $5 \cdot 3$ & $21 \cdot 1$ & $5 \cdot 3$ & $\ldots$ & $5 \cdot 3$ & - & - & $6.3 \cdot 0$ & 19 \\
\hline Blepharitis & $73 \cdot 3$ & $6 \cdot 7$ & $3 \cdot 3$ & - & $6 \cdot 7$ & - & - & $10 \cdot 5$ & 30 \\
\hline Postoperative infections & $34 \cdot 4$ & $16 \cdot 5$ & $0 \cdot 4$ & $5 \cdot 1$ & $1 \cdot 2$ & - & - & $42 \cdot 1$ & 235 \\
\hline$\%$ Overall positivity & $20 \cdot 8(37 \cdot 4)$ & $24 \cdot 6(44 \cdot 2)$ & $4 \cdot 8(8 \cdot 7)$ & $3 \cdot 1(5 \cdot 6)$ & $1 \cdot 2(2 \cdot 1)$ & $0.4(0 \cdot 8)$ & $0 \cdot 4(0 \cdot 8)$ & $44 \cdot 2$ & 823 \\
\hline
\end{tabular}

${ }^{*}$ One case Ps. aeruginosa + Acinetobacter. + Staph. aureus + Entero-aerogenes + Pr. mirabilis. $\ddagger$ One case Staph. aureus + Acinetohacter

Percentages are of the total for each group, except those in parentheses, which are percentages of the total positive cultures

Table 2 Antibiotic resistance patterns (\%) of bacteria isolated from ocular tissues

\begin{tabular}{|c|c|c|c|c|c|c|c|c|c|c|}
\hline $\begin{array}{l}\text { Name of the } \\
\text { organism }\end{array}$ & $\begin{array}{l}\text { No. of } \\
\text { strains } \\
\text { tested }\end{array}$ & $P$ & $S$ & $T$ & $\mathrm{CH}$ & $E$ & $F$ & $G$ & $(1)^{*}$ & $P B$ \\
\hline Staph. aureus & 91 & $\begin{array}{l}97 \cdot 8 \\
(90 \cdot 7)\end{array}$ & $\begin{array}{l}66 \cdot 6 \\
(59 \cdot 7)\end{array}$ & $\begin{array}{l}69 \cdot 2 \\
(67 \cdot 2)\end{array}$ & $\begin{array}{l}29 \cdot 6 \\
(57 \cdot 4)\end{array}$ & $\begin{array}{l}36 \cdot 2 \\
(58 \cdot 3)\end{array}$ & $\begin{array}{l}69 \cdot 2 \\
(42 \cdot 1)\end{array}$ & $\begin{array}{l}36 \cdot 2 \\
(19 \cdot 9)\end{array}$ & $\begin{array}{l}(0 \cdot 0) \\
-\end{array}$ & NT \\
\hline Staph. epidermidis & 37 & $\begin{array}{l}100 \cdot 0 \\
(89 \cdot 4)\end{array}$ & $\begin{array}{l}78 \cdot 3 \\
(76 \cdot 8)\end{array}$ & $\begin{array}{l}8.3 \cdot 7 \\
(8.5 \cdot 4)\end{array}$ & $\begin{array}{l}4(0 \cdot 5 \\
(79 \cdot 4)\end{array}$ & $\begin{array}{l}62 \cdot 1 \\
(78 \cdot 8)\end{array}$ & $\begin{array}{l}7(0 \cdot 2 \\
(32 \cdot 4)\end{array}$ & $\begin{array}{l}37 \cdot 8 \\
(27 \cdot 1)\end{array}$ & $\begin{array}{l}(0 \cdot 0 \\
-\end{array}$ & NT \\
\hline Str. pneumoniae & $37^{\dagger}$ & $91 \cdot 8$ & $54 \cdot 0$ & $54 \cdot()$ & $5 \cdot 4$ & $21 \cdot 6$ & $64 \cdot 8$ & $51 \cdot 3$ & NT & NT \\
\hline Ps. aeruginosa & $14 \ddagger$ & NT & $\begin{array}{l}64 \cdot 2 \\
(56 \cdot 3)\end{array}$ & $\begin{array}{l}85.7 \\
(83.9)\end{array}$ & $\begin{array}{l}71 \cdot 4 \\
(88 \cdot 5)\end{array}$ & NT & $\begin{array}{l}78 \cdot 5 \\
(21 \cdot 8)\end{array}$ & $\begin{array}{l}28 \cdot 5 \\
(3 \cdot 4)\end{array}$ & NT & $\begin{array}{l}21 \cdot 4 \\
(27 \cdot 6)\end{array}$ \\
\hline Acinetobacter & 9 & NT & $\begin{array}{l}44 \cdot 4 \\
(47 \cdot 6)\end{array}$ & $\begin{array}{l}55 \cdot 5 \\
(33 \cdot 3)\end{array}$ & $\begin{array}{l}44 \cdot 4 \\
(28 \cdot 6)\end{array}$ & NT & $\begin{array}{l}66 \cdot 6 \\
(19 \cdot())\end{array}$ & $\begin{array}{l}11 \cdot 1 \\
(23 \cdot 8)\end{array}$ & NT & NT \\
\hline Fermenting coliforms & 6 & NT & $\begin{array}{l}66 \cdot 6 \\
(30) \cdot(0)\end{array}$ & $\begin{array}{l}66 \cdot 6 \\
(9() \cdot())\end{array}$ & $\begin{array}{l}33 \cdot 3 \\
(50 \cdot())\end{array}$ & NT & $\begin{array}{l}66 \cdot 6 \\
(0 \cdot(0)\end{array}$ & $\begin{array}{l}16 \cdot 6 \\
(() \cdot())\end{array}$ & NT & NT \\
\hline$\%$ Overall resistance & 194 & $\begin{array}{l}93 \cdot 8 \\
(89 \cdot 2)\end{array}$ & $\begin{array}{l}61 \cdot 8 \\
(61 \cdot 1)\end{array}$ & $\begin{array}{l}69 \cdot 5 \\
(72 \cdot 8)\end{array}$ & $\begin{array}{l}3(0 \cdot 9 \\
(64 \cdot 9)\end{array}$ & $\begin{array}{l}38 \cdot 7 \\
(66 \cdot 1)\end{array}$ & $\begin{array}{l}69 \cdot 0 \\
(32 \cdot 6)\end{array}$ & $\begin{array}{l}36 \cdot 5 \\
(19 \cdot 1)\end{array}$ & $(0 \cdot 0$ & $\begin{array}{l}21 \cdot 4 \\
(27 \cdot 6)\end{array}$ \\
\hline
\end{tabular}

Abbreviations: $P=$ penicillin, $S=$ streptomycin, $T=$ tetracycline, $\mathrm{CH}=$ chloramphenicol, $\mathrm{E}=$ erythromycin, $\mathrm{F}=$ framycetin, $\mathrm{G}=$ gentamycin , $\mathrm{CL}=$ cloxacillin, $\mathrm{PB}=$ polymyxin $\mathrm{B}, \mathrm{NT}=$ not tested. Figures in parentheses denote percentages in our previous study.

* Sensitivity testing to cloxacillin was started in 1980

+ Sensitivity testing of pneumococci was also started in 1980

$\ddagger$ One strain resistance to all, was sensitive to tobramvcin.

Table 3 Antibiotic resistance patterns (\%) of bacteria isolated from postoperative infections of the eve

\begin{tabular}{|c|c|c|c|c|c|c|c|c|c|c|}
\hline Name of the organism & $\begin{array}{l}\text { No. of } \\
\text { strains } \\
\text { tested }\end{array}$ & $P$ & $S$ & $T$ & $\mathrm{CH}$ & $E$ & $F$ & $G$ & $C l$ & $P B$ \\
\hline Staph. aureus & 81 & $100 \cdot()$ & $\varphi() \cdot()$ & $91 \cdot 3$ & $77 \cdot 7$ & $85 \cdot 1$ & $98 \cdot 7$ & $93 \cdot 8$ & $3 \cdot 7$ & NT \\
\hline Staph. epidermidis & 39 & $100 \cdot()$ & $84 \cdot 6$ & $89 \cdot 7$ & $58 \cdot 9$ & $69 \cdot 2$ & $87 \cdot 1$ & $79 \cdot 4$ & $2 \cdot 5$ & NT \\
\hline Str. pneumoniae & 1 & \multicolumn{4}{|c|}{ Resistant to P. ST. T. and F } & & & & NT & NT \\
\hline Ps. aeruginosa & 12 & NT & $75 \cdot()$ & $66 \cdot 6$ & $75 \cdot()$ & NT & $75 \cdot()$ & $58 \cdot 3$ & NT & $\begin{array}{l}() \\
(0 \cdot())\end{array}$ \\
\hline Acinetobacter & 3 & $100 \cdot()$ & $3.3 \cdot 3$ & $66 \cdot 6$ & $0 \cdot()$ & NT & $33 \cdot 3$ & $0 \cdot()$ & NT & NT \\
\hline$\%$ Overall resistance & 136 & $10(0) \cdot()$ & $86 \cdot 0$ & $88 \cdot 2$ & $69 \cdot 8$ & $79 \cdot 3$ & $91 \cdot 9$ & $83 \cdot 8$ & $3 \cdot 3$ & $(0 \cdot 0$ \\
\hline
\end{tabular}

Abbreviations as under Table 2.

The use of swabs wetted in broth for collection or the use of Stuart's medium during transport to the laboratory is clearly indicated and recommended. Only $2.4 \%$ of the cultures were mixed, diphtheroids being one of the organisms. Though the normal sac appears to be colonised mainly by Staph. epidermidis or Staph. aureus, other organisms like Acinetobacter calcoaceticus, Pseudomonas aeruginosa and Strepto- 
coccus pneumoniae were also isolated. The number of sterile cultures was also higher than in other reports.

Conjunctivitis in this series was chiefly caused by Staph. aureus, Str. pneumoniae, nonfermenting Gram-negative organisms, and fermenting coliforms. None of our cases yielded Str. viridans, Neisseria, Moraxella, or Haemophilus sp. ${ }^{3}$ The high proportion of sterile cultures in this group, and the absence of these organisms from frank mucopurulent discharge, strongly suggest that routine inclusion of more media like chocolate agar is desirable. All the 6 isolates of pneumococci were from children under 3 years, and none from adults. ${ }^{3}$

We isolated 25 strains of Str. pneumoniae from 61 infants with dacryocystitis but only one from 14 adults. One adult yielded Staph. aureus not only from the eyes but also from the nose. In our study dacryocystitis in children seems to be caused mainly by pneumococci, though other pathogens may also be infrequently seen. It is noteworthy that over $90 \%$ of our isolates were resistant to penicillin-a finding hitherto infrequently reported.

We cultured 73 eyes with corneal ulceration, clinically diagnosed as bacterial in origin, but 28 yielded no growth. In the remaining $82.2 \%$ were the staphylococci (Staph. epidermidis 19, Staph. aureus 18). Haemophilus sp. and Str. pyogenes were never isolated. We did isolate Ps. aeruginosa, Str. pneumoniae, Proteus mirabilis, and Enterobacter aerogenes. These findings are similar to those reported elsewhere. ${ }^{35}$

A total of 31 discharging sockets yielded no growth in $35.4 \%$. The remainder were associated with staphylococci, pneumococci, Ps. aeruginosa, and Acinetobacter. Staph. aureus was isolated from $22.5 \%$ of the sockets, ${ }^{67}$ whereas only $5.3 \%$ of the fellow eyes harboured it. Interestingly, $63.0 \%$ of the fellow eyes did not contain any organism, though both the eyes were simultaneously swabbed and cultured. It would be more interesting to record that the strains of Staph. epidermidis isolated from fellow eyes were of different sensitivity patterns when compared with those from the sockets. The latter were resistant to many antibiotics.

Our results on cases of blepharitis differ significantly from those reported by Seal et al. ${ }^{3}$ Of the 30 eyes cultured by us only 3 were sterile. Of the remainder 22 $(73.3 \%)$ isolates were Staph. aureus. The strains of Staph. epidermidis in this category were the fewest.

Postoperative infected eyes (235) were also cultured. In this group the material was collected either from the conjunctiva, surgical wound, buckle, or corneal surface or was in the form of aqueous or vitreous aspirates. Of the 235 samples examined $42.1 \%$ were sterile, the figure nearly similar to other category of lesions. Staphylococci both coagulase positive and negative predominated. Staph. aureus outnumbered Staph. epidermidis, and next in frequency was Ps. aeruginosa. Nearly $60 \%$ of the 136 positive cultures were strains of Staph. aureus, whereas Staph. epidermidis accounted for only $28.6 \%$. Here also nearly all the strains were resistant to most of the antibiotics.

The role of Staph. epidermidis in ocular disease has been the subject of much controversy recently, though it is known to be a potential pathogen after insertion of a surgical prosthesis and in urinary tract infections. $^{89}$ In ocular infections, also, sporadic reports have appeared of its being pathogenic in corneal ulcers, ${ }^{10}$ postoperative infections, ${ }^{11-13}$ and blepharoconjunctivitis. ${ }^{1415}$ Much experimental evidence has also accumulated to suggest that it caused corneal lesions of varying severity and also blepharitis in rabbits. ${ }^{16-18}$ It therefore does not seem wise to ignore these organisms as commensals if they are isolated in some numbers from infected sites in view of the claims by clinical colleagues that corneal ulcers or postoperative infections due to this species responded to the timely application of appropriate antibiotics. ${ }^{131920}$ We therefore investigate routinely all cases of corneal ulcers, postoperative infections, chronic cases of conjunctivitis, and blepharitis for coagulase-negative staphylococci and report the sensitivities of the isolates. Interestingly, $30 \%$ of such isolates were shown to be capable of eliciting dermonecrotoxicity for rabbit skin, indicating the presence of alpha toxin. Highly dermonecrotoxic strains were haemolytic also for sheep and rabbit erythrocytes. ${ }^{21}$

Since we reported our previous study ${ }^{22}$ certain notable differences have occurred in the resistance patterns of these organisms. For instance, the least overall resistance of $19.1 \%$ to gentamicin and $32.6 \%$ to framycetin has risen to $36.6 \%$ and $69.0 \%$ respectively. The number of strains resistant to penicillin has further increased. There has, however, been a considerable decline in percentage resistance of chloramphenicol and erythromycin. These 2 antibiotics are the second best to cloxacillin in treating staphylococcal infections. Chloramphenicol is also as effective as gentamicin against streptococci and infections due to Gram-negative organisms. The $100 \%$ resistance of penicillin to postoperative strains of staphylococci is noteworthy, as also is their increased resistance to other antibiotics. It is possible that the most frequently isolated strains of staphylococci from postoperative infections sensitive to either cloxacillin alone or to cloxacillin and chloramphenicol only are hospital strains. Accordingly cloxacillin, chloramphenicol, and gentamicin are the most frequently used topical ophthalmic preparations in our hospital. But polymyxin B is the first choice in infections due to $P$ s. aeruginosa. 


\section{References}

1 Perkins RE, Kundsin RB. Pratt MV, Abrahamsen I, Leibowitz HM. Bacteriology of normal and infected conjunctiva. J Clin Microbiol 1975; 1: 147-9.

2 Brook I. Anaerobic and aerobic bacterial flora of acute conjunctivitis in children. Arch Ophthalmol 1980; 98: 833-5.

3 Seal DV, Barrett SP, McGill JI. Aetiology and treatment of acute bacterial infection of the external eye. Br J Ophthalmol 1982; 66: 357-60.

4 Bauer AW, Kirby WMM, Sherris JC. Turck M. Antibiotic susceptibility testing to a standardised single disk method. Am J Clin Pathol 1968; 21: 93-6.

5 Locatcher-Khorazo D, Seegal BC. Microbiology of the eve. St Louis: Mosby, 1972.

6 Christensen JN, Fahmy JA. The bacterial flora of the conjunctival anophthalmic socket in glass prosthesis carriers. Acta Ophthalmol (Kbh) 1974; 52: 801-9.

7 Miller SD, Smith RE, Dippe DW. Bacteriology of the socket in patients with prosthesis. Can J Ophthalmol 1976; 11: 126-9.

8 Forse RA. Dixon C. Bernard K. Martinez I. McLean APH. Meakins JL. Staphylococcus epidermidis-an important pathogen. Surgery 1979; 86: 507-14.

9 Editorial: Coagulase-negative staphylococci. Lancet 1981; i: $139-40$

10 Meers PD, Whyte W, Saudys G. Coagulase negative staphylococci and micrococci in urinary tract infections. $J$ Clin Pathol 1975; $28: 270-3$

11 Paed L. Crump J, Maskell R. Staphylococci as urinary pathogens. J Clin Pathol 1977; 30: 127.
12 Khosla PK, Prakash O, Agarwal LP. Clinico-bacteriological study of soframycin in conjunctival flora (normal and corneal ulcer cases). East Arch Ophthalmol 1973; 1: 212-20.

13 Khosla PK, Angra SK, Agarwal LP. Postoperative staphylococcal infection. East Arch Ophthalmol 1964; 2: 240-2.

14 Allen MF, Mangiarcine AB. Bacterial endophthalmitis after cataract extraction. Arch Ophthalmol 1964; 72: 454-62.

15 Valenton MJ, Brubaker RF, Allen HF. Staphylococcus epidermidis (albus) endophthalmitis (report of two cases after cataract extraction). Arch Ophthalmol 1973; 89: 94-6.

16 Valenton MJ, Okumoto M. Toxin producing strains of Staphylococcus epidermidis. Arch Ophthalmol 1973; 89: 186-9.

17 Smolin G, Okumoto M. Staphylococcal blepharitis. Arch Ophthalmol 1977; 95: 812-6.

18 Agarwal LP, Nair RV, Sood NN, Mahajan VM. Role of trauma and corticosteroids in qausation of corneal pathology by commensals. East Arch Ophthalmol 1976; 4: 1-6.

19 Mahajan VM, Alexander TA, Jain RK, Agarwal LP. Role of coagulase negative staphylococci and micrococci in ocular disease. J Clin Pathol 1980; 33: 1169-73.

20 Agarwal LP. Alexander TA, Mahajan VM, Ratnakar KS. Staphylococcus albus in ocular infections-a clinicobacteriological correlation and experimental study. East Arch Ophthalmol 1979; 7: 1-6.

21 Mahajan VM. Reddy TN. Agarwal LP. Toxigenic strains of Staphylococcus epidermidis and their experimental corneal pathogenicity in rabbits. Int Ophthalmol 1982; 5: 155-61.

22 Mahajan VM. Common organisms in the human eye and their susceptibility to antibiotics. East Arch Ophthalmol 1978; 6: 217-23. 